\section{Soil Amendments, Hole Depth, and Top Pruning at Transplanting Have Small Effect on Pecan Trees}

\author{
Ray E. Worley \\ University of Georgia, Coastal Plain Experiment Station, Tifton, \\ GA 31793
}

Additional index words. Carya illinoensis, lime, manure

Soil amendments added to the backfill soil at transplanting were evaluated using 1-mtall 'Wichita' and 2-m-tall 'Desirable' pecan [Carya illinoensis (Wangenh.) K. Koch] trees. Amendments per hole were none, $227 \mathrm{~g} 10 \mathrm{~N}-$ 4.4P-8.3K, $454 \mathrm{~g} \mathrm{10N-4.4P-8.3K,} 918 \mathrm{~g}$ dolomite, $11.4 \mathrm{~kg}$ dry cow manure $(0.50 \mathrm{~N}-$ $0.22 \mathrm{P}-0.41 \mathrm{~K}$ ), and $454 \mathrm{~g} 10 \mathrm{~N}-4.4 \mathrm{P}-8.3 \mathrm{~K}$ plus $918 \mathrm{~g}$ dolomite, replicated four times on 'Desirable' and twice on 'Wichita' in a randomized complete block design. Vigor ratings, which included growth, color, and general appearance of the tree, were made 23 Sept. 1988, 11 May and 17 Oct. 1989, and 1 Oct. 1990. Trunk circumference and height were measured on the latter two dates. Tree vigor ratings, trunk circumference, and height were not affected by treatments (data not shown).

A second study compared 2-m-tall 'Desirable' trees when 0 , one-third, or one-half of the top was removed at transplanting. Treatments were replicated eight times in a randomized complete block design. Vigor rating on 23 Sept. 1988 was higher when

Received for publication 28 Dec. 1990. The cost of publishing this paper was defrayed in part by the payment of page charges. Under postal regulations, this paper therefore must be hereby marked advertisement solely to indicate this fact.

${ }^{2}$ Vigor rating: 1 = poor, 9 = very high. Linear component significant at $P=0.05$. one-half of the top was removed than when none or one-third of the top was removed (data not shown). Treatment differences for vigor ratings on 11 May and 17 Oct. 1989 and 1 Oct. 1990, and trunk circumference and height on 17 Oct. 1989 and 1 Oct. 1990 were not significant. One tree from each treatment died. The responses from topping in this study were less than those obtained in Oklahoma (Smith and Johnson, 1981, but similar to those of Shoup et al. (1981) and Hummel and Johnson.

A third experiment compared transplant hole depths of 30,60, and $90 \mathrm{~cm}$ (all $60 \mathrm{~cm}$ in diameter) in a randomized complete block design with three replications each of 'Desirable' and 'Wichita'. A fourth treatment, added to represent the minimum a grower would do in transplanting and the recom- mendation of a Texas nurseryman, was a hole made with a hand posthole digger $(\approx 20 \mathrm{~cm}$ in diameter and $<90 \mathrm{~cm}$ deep). The hole was deep enough to accommodate the taproot without pruning, and lateral roots were trimmed to fit each hole.

Vigor rating increased with hole depth at all dates, except 1 Oct. 1990. Trunk circumference and height were positively related to hole depth on 17 Oct. 1989 (Table 1). Trees planted in $20 \times 90-\mathrm{cm}$ hand-dug holes had lower vigor ratings, with smaller trunk circumference and height than those planted in $60 \times 90-\mathrm{cm}$ holes on 23 Sept. 1988 and 17 Oct. 1989 (data not shown). Two of the four trees that died in this study were from the $30-\mathrm{cm}$ hole depth and one each died from the other two depths. None died when planted in the post hole. Dead trees were treated as missing values for all tests.

\section{Literature Cited}

Hummel, R.L. and C.R. Johnson. 1986. Influence of pruning at transplant time on growth establishment of Liquidamber styraciflua L., sweet gum J. Environ. Hort. 4(3):83-86.

Shoup, S., R. Reavis, and C.E. Whitcomb. 1981. Effects of pruning and fertilizers on establishment of bareroot deciduous trees. J. Arboriculture 7:155-157.

Smith, M.W. and J.L. Johnson. 1981. Effect of top pruning and root length on growth and survival of transplanted pecan trees. Pecan Quarterly $15(2): 20-22$.

Table 1. Effect of transplant hole depth on pecan tree vigor and growth.

\begin{tabular}{|c|c|c|c|c|c|c|c|c|}
\hline \multirow{2}{*}{$\begin{array}{l}\text { Hole } \\
\text { depth } \\
(\mathrm{cm}) \\
\end{array}$} & \multicolumn{4}{|c|}{ Vigor rating ${ }^{z}$} & \multicolumn{2}{|c|}{$\begin{array}{c}\text { Trunk circumf } \\
(\mathrm{cm})\end{array}$} & \multicolumn{2}{|c|}{$\begin{array}{c}\text { Tree ht } \\
(\mathrm{cm})\end{array}$} \\
\hline & $\begin{array}{l}23 \text { Sept. } \\
1988 \\
\end{array}$ & $\begin{array}{c}11 \text { May } \\
1989\end{array}$ & $\begin{array}{c}17 \text { Oct. } \\
1989\end{array}$ & $\begin{array}{c}1 \text { Oct. } \\
1990\end{array}$ & $\begin{array}{c}17 \text { Oct. } \\
1989\end{array}$ & $\begin{array}{c}1 \text { Oct. } \\
1990\end{array}$ & $\begin{array}{c}17 \text { Oct. } \\
1989\end{array}$ & $\begin{array}{l}1 \text { Oct. } \\
1990 \\
\end{array}$ \\
\hline $\begin{array}{l}30 \\
60 \\
90 \\
\end{array}$ & $\begin{array}{l}0.4^{y} \\
3.6 \\
5.3\end{array}$ & $\begin{array}{l}3.3^{y} \\
4.1 \\
6.0 \\
\end{array}$ & $\begin{array}{l}1.4^{y} \\
3.3 \\
5.6\end{array}$ & $\begin{array}{l}5.1 \\
6.8 \\
7.4 \\
\end{array}$ & $\begin{array}{l}5^{y} \\
8 \\
9\end{array}$ & $\begin{array}{r}8 \\
12 \\
14 \\
\end{array}$ & $\begin{array}{r}79 \\
130 \\
145\end{array}$ & $\begin{array}{l}150 \\
185 \\
208\end{array}$ \\
\hline
\end{tabular}

